Old Dominion University ODU Digital Commons

Educational Foundations \& Leadership Faculty

Publications

Educational Foundations \& Leadership

2019

\title{
Liberal Education and the Capitalocene in American Higher Education
}

Laura Smithers

Old Dominion University

Follow this and additional works at: https://digitalcommons.odu.edu/efl_fac_pubs

Part of the Higher Education Commons, and the Social and Philosophical Foundations of Education Commons

\section{Repository Citation}

Smithers, Laura, "Liberal Education and the Capitalocene in American Higher Education" (2019). Educational Foundations \& Leadership Faculty Publications. 55.

https://digitalcommons.odu.edu/efl_fac_pubs/55 


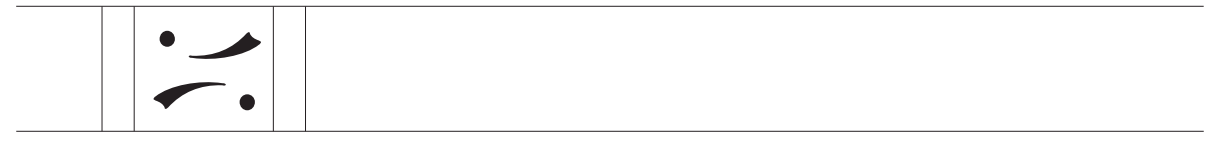

\title{
4. Libeval Education and the Capitalocene in American Higher Education
}

\author{
Laura Elizabeth Smithers \\ Old Dominion University
}

Abstract: Data-driven control is remaking American higher education as the Capitalocene is remaking environment around us. In higher education, how might we orientate the queer potential of liberal education to produce the conditions of possibility of an Earth beyond the Capitalocene and data-driven control, an Earth that produces expansive notions of student success and racially just futures? I take up this inquiry in three sections. First, I establish relations between the orientation of the Capitalocene and the apparatus of data-driven control to develop a critical new materialisms analytic. I then diffract the practices of a student success initiative at a west coast university through this analytic. I end with an exploration of the potential of liberal education, as understood to queer the surface between the determinate and the indeterminate, to create the conditions of anti-instrumentalist, anti-racist change.

Keywords: data-driven control, queer, liberal education. capitalocene, critical materialism

World War III trends on Twitter, the words of a sitting U.S. Senator to describe the foreseeable consequences of the actions of his own party's president. American citizens struggle to survive weeks after a second major hurricane strikes, while an administration throws towels and snack packs to this island with big water around it, brown people on it, and flows of debt through it. Fires rage in the West, immanent re/constructions of snowmelt, sun, sprawl, teenage ennui, winds, trails, Instagram, the outdoor recreation industry, devastation, loss of life, rebirth. The local paper details a public university's plan to replace its current $50 \%$ plus one in-state enrollment strategy to a plurality 
out-of-state and international enrollment strategy, another remaking of an educational institution through capital flows. ${ }^{1}$ The problems of our current moment share relations. Knowing our world through these indeterminate and determinate relations as its primary ontological unit ${ }^{2}$ gives us tools for collective change.

The particular assemblage of indeterminate and determinate relations in this moment of the Capitalocene, societies of control, amplifies the division between humans and nature, creating determinate dividuals of each to be consumed as data and capital. ${ }^{3}$ The entanglement of the Capitalocene and control has the power to devastate higher education as it devastates the environment around us. In the Capitalocene, determinate individual freedom realized through relations of capital is the orientation of the radical reshaping of the human and more-than-human Earth, a reshaping whose effects demonstrate the fiction of the individual and highlight the escape of individual actions into the ground, atmosphere, humans, "markets," future, built and yet-to-be-built environment, and hierarchies within and among these, an indeterminacy so potent as to shift geologic time.

This paper focuses on the impacts of knowing undergraduate student success through the orientation of the Capitalocene and the apparatus of control. ${ }^{4}$ Specifically, I explore the orientation of the Capitalocene as it manifests in the practices of a student success initiative at a west coast AAU university (hereafter referred to as Great State University or GSU), an initiative which equates student success with "on-time" graduation and also includes contemporaneous campus commitments to equity and liberal education. Through this particular site, I explore the reality the Capitalocene and control produces in undergraduate education, and ask how might we hold futures of undergraduate education radically open. ${ }^{5}$

Under the current organization of heterogeneous elements particular to higher education, data-driven control, the centering of students and of

I Saul Hubbard, “Out-of-State 'O'ffensive: UO Widening Net to Recruit Nonresidents to Reverse Enrollment Dip,” Eugene Register-Guard, accessed October 8, 2017. http:// registerguard.com $/ \mathrm{rg} /$ news/local/36001005-75/out-of-stateoffensive.html.csp.

2 Brian Massumi, Parables for the Virtual: Movement, Affect, Sensation (Durham, NC: Duke University Press, 2002).

3 Gilles Deleuze, "Postscript on the Societies of Control," October 59 (1992): 3-7.

4 Sara Ahmed, Queer Phenomenology: Objects, Orientations, Others (Durham, NC: Duke University Press, 2006); Karen Barad, Meeting the Universe Halfway: Quantum Physics and the Entanglement of Matter and Meaning (Durham, NC: Duke University Press, 2007).

5 Barad, Meeting the Universe Halfway. 
diversity are the primary justifications for, instead, embracing flows of data, capital, training, credentials, student academic risk, and other areas of undergraduate education rendered determinate and exchangeable. ${ }^{6}$ Areas outside of the capture of data-driven control, here liberal education as conceived of as a process irreducible to outcomes and systemic racism as irreducible to any determinate actor or action, fade to the background even as actions in their name are valorized. Adapting Sara Ahmed's work, how might we use the queer concepts of indeterminacy and liberal education to enact change? ${ }^{7}$ In American higher education (AHE), how might we orientate ${ }^{8}$ the indeterminacy of liberal education to produce the conditions of possibility of an Earth beyond the Capitalocene and control, an Earth that produces students with radically open (to include racially just) futures?

Critical new materialisms offer a potential theoretical intervention that takes immanent formations of power, governmentality, and capitalism as its orientation. ${ }^{9}$ The named literature in this area of the new materialisms is less developed, so here I place a wide variety of concepts, authors, and orientations into relation to forward what a critical materialism might be. This promiscuous reading, ${ }^{10}$ or perhaps a critical new materialism in formation, ${ }^{11}$ offers a theoretical intervention on the particularities of this site, as orientated by the Capitalocene and the apparatus of control. It centers its analysis on the enmeshment of environments, capital, humans, matter, and life, as well as the indeterminate and radically open new. In what follows, I use this information-critical new materialism as the relational space through which the orientation of the Capitalocene, the apparatus of control, and the empirical context of Great State University's student success initiative takes shape. ${ }^{12}$

6 Laura E. Smithers, “A History of the Present of Student Success in Undergraduate Education." Unpublished manuscript, last modified September 18, 2018. Microsoft Word file.

7 Ahmed, Queer Phenomenology. Ahmed discusses the potentials of queer objects in this work of phenomenology. Here, I shift queer objects to queer concepts to adapt Ahmed's insights for the critical new materialisms, where objects are themselves in need of explanation. See next paragraph for more on this style of promiscuous reading.

8 Ibid.

9 Diana Coole and Samantha Frost, "Introducing the New Materialisms," in New Materialisms: Ontology, Agency, and Politics, ed. Diana Coole and Samantha Frost (Durham, NC: Duke University Press, 2010), 1-43.

10 Becky Atkinson, "Was Jane Addams a Promiscuous Pragmatist?" International Journal of Qualitative Studies in Education 26, no. 5 (2013): 610-24.

11 Beyoncé, Formation. Columbia, 2016, digital.

12 Alecia Y. Jackson and Lisa A. Mazzei, Thinking with Theory in Qualitative Research: Viewing Data Across Multiple Perspectives (New York: Routledge, 2012). 
This promiscuous diffraction ${ }^{13}$ explores the entanglement of capitalism, racial injustice, and an instrumentalized education, as well as the queer re/orientations that might come from embracing indeterminacy.

\section{Naming and Worldmaking: Creating This (Aionic) Epoch}

The Capitalocene names the work of indeterminate relations acting with and through capital to bring about the epoch of the Anthropocene; it is "an ugly word for an ugly system." 14 The Capitalocene centers capitalism not as a static economic or social system, but as "a way of organizing nature." 15 If the Anthropocene is the designation for a new epoch of geological time marked by human influence on the Earth, following Jason Moore, I use Capitalocene here to shift our orientation ever so slightly to center the indeterminate relations which constitute the Anthropocene as our current state of determination. ${ }^{16}$ Moore turns to the Capitalocene as a naming and concept in part because he reads the literature of the Anthropocene as saturated with a determinate Green Arithmetic: Nature plus Society equals Anthropocene. ${ }^{17}$ However, scholars who read in different literatures call upon conceptions of the anthropocene in excess of the geological Anthropocene steeped in relationality and indeterminacy. Claire Colebrook uses the term "Anthropocene" to argue against the formulation of Green Arithmetic, and in favor of a posthumanist introspection into the indeterminate, or indifferent possibilities of the world as it is and as it might have been. ${ }^{18}$ Stacy Alaimo and many others also capture the anthropocene firmly within posthumanism and the new materialisms, contra Moore's claim. ${ }^{19}$ There are also questions as to the existence

13 Barad, Meeting the Universe Halfway.

14 Jason W. Moore, Capitalism in the Web of Life: Ecology and the Accumulation of Capital (London: Verso, 2015), 3.

15 Ibid., 2, italics in the original.

16 Moore does not use the language of indeterminate; instead, he describes "an open conception of life-making, one that views the boundaries of the organic and inorganic as ever-shifting. It is a multi-layered relation through which there are no basic units, only webs within webs of relations...." Ibid., 7-8.

17 Ibid.

18 Claire Colebrook, "We Have Always Been Post-Anthropocene: The Anthropocene Counterfactual," in Anthropocene Feminism, ed. Richard Grusin (Minneapolis: University of Minnesota Press, 2017), 1-20.

19 Stacy Alaimo, Exposed: Environmental Politics and Pleasures in Posthuman Times (Minneapolis: University of Minnesota Press, 2016); see also Jasmine B. Ulmer, "Posthumanism as Research Methodology in the Anthropocene," International Journal of Qualitative Studies in Education 30, no. 9 (2017): 832-48. 
of either, the politics of an anthropocene that implicates all humans in the destructive actions of the White West, anthropos enacting another nature-culture divide, the naming of the Capitalocene as enacting a limiting focus on capitalism, and namings of this era that bypass messy human and capital reference altogether. ${ }^{20}$ I use the naming of the Capitalocene throughout advisedly to both signal the entangled relations of this historical-geological epoch and as an act of citational promiscuity, a means to include a web of capital relations as an experimentation in forming a critical new materialism.

The problem of American higher education shares relational terms with the problem of our Earth: a "capitalization and appropriation"21 of the university, or the deterritorializing of the university into flows of capital. ${ }^{22}$ These relations have sidelined a rich conception of liberal education ${ }^{23}$ as the production of radically open futures in favor of a measurement science of student success in which desired outcomes can be determined in advance, placed within predictive algorithms, and impacted by variations of inputs and environments. ${ }^{24}$ Undergraduate education has been capitalized and appropriated, and the university has been remade by flows of dividuals, including

20 Eileen Crist, "On the Poverty of our Nomenclature," in Anthropocene or Capitalocene? Nature, History, and the Crisis of Capitalism, ed. Jason W. Moore (Oakland, CA: PM Press, 2016), 14-33; Donna Haraway, "Anthropocene, Capitalocene, Plantationocene, Chthulucene: Making Kin," Environmental Humanities 6 (2015): 159-65; Jill S. Schneiderman, "The Anthropocene Controversy," in Anthropocene Feminism, ed. Richard Grusin (Minneapolis: University of Minnesota Press, 2017), 169-95.

21 Moore, Capitalism in the Web of Life, 214.

22 Gilles Deleuze and Felix Guattari, Anti-Oedipus: Capitalism and Schizophrenia (New York: Penguin Books, 2009); Sheila Slaughter and Gary Rhoades, Academic Capitalism and the New Economy: Markets, State, and Higher Education (Baltimore, MD: The Johns Hopkins University Press, 2004).

23 AAC\&U, What Is a 21st Century Liberal Education? (Washington, DC: American Association of Colleges \& Universities, 2017). https://aacu.org/leap/what-is-a-lib eral-education.

24 Kenneth A. Feldman and Theodore M. Newcomb. The Impact of College on Students, Volume 1: An Analysis of Four Decades of Research (San Francisco, CA: Jossey-Bass Inc., Publishers, 1969); Alexander W. Astin, Four Critical Years: Effects of College on Beliefs, Attitudes, and Knowledge (San Francisco, CA: Jossey-Bass, 1977); George D. Kuh and Carol Geary Schneider, High-Impact Practices: What They Are, Who Has Access to Them, and Why They Matter (Washington, DC: American Association of Colleges and Universities, 2008); Michelle Burke, Amelia Parnell, Alexis Wesaw, and Kevin Kruger, Predictive Analysis of Student Data (Washington, DC: NASPA: Student Affairs Administrators in Higher Education, 2017). https://www.naspa.org/ images/uploads/main/PREDICTIVE_FULL_4-7-17_DOWNLOAD.pdf. 
capital. This is a problem of the determination of the world we take as real and measurable, of the making-determinate of forms and substances into particular orientated flows. What follows explores the possibilities rendered by problematizing the determinate, inquiring not at the level of the real and measurable, but the relations within the apparatus that actualize the real and measurable as such. ${ }^{25}$ In order to create radically open spaces, we must examine indeterminacy, the real that exists prior to and alongside the cuts that determine the words and things of our fractured times.

\section{Entanglement, indeterminacy, capitalocene}

The Capitalocene is marked by the orientation and movement of human and other-than-human actants in particular enmeshed and entangled preindividual flows that organize value relations. Relations of capital orientate, as do relations of race, and sexuality, and gender, and nationality, and, and, and... in a multilayered web of relations, there is no privileged, agential, disentangled unity to hold singularly responsible. The central problem of the Capitalocene is not a search for a responsible unit for our destruction (and thus our salvation), but rather the particular formation of the apparatus organizing the preindividual flows that mark the Capitalocene. Moore, through Marx, names this historical apparatus the "law of value," 26 dates it to the development of capitalism, and marks it as a quasi-cause of the determinations that come. Deleuze and Foucault name several apparatuses of power during this time as precursors to our current apparatuses of control biopolitics biopower, modern instantiations of the law of value. ${ }^{27}$

These assemblages organize heterogeneous elements through rendering matter of all levels of animacy determinate and of exchangeable value. Forms of matter and meaning are made discrete, then set in exchange with other forms of dividuated matter. These are colonizing assemblages, they seek to "maintain control not only over the measured and measurable territories, but also to penetrate into uncontrolled realms not previously desired and to

25 Barad, Meeting the Universe Halfway.

26 Ibid., 216.

27 Deleuze, "Postscript;" Michel Foucault, The Birth of Biopolitics: Lectures at the Collège de France 1978-1979 (New York: Palgrave Macmillan, 2008), The History of Sexuality, Volume 1: The Will to Know (New York: Vintage Books, 1990); Moore, Capitalism in the Web of Life; Thomas Nail, "Biopower and Control," in Between Deleuze and Foucault, ed. Nicolae Morar, Thomas Nail, and Daniel W. Smith (Chicago: University of Chicago Press, 2016), 247-63. 
measure them as exactly and comprehensively as possible." ${ }^{28}$ In doing so, they individuate the Earth into (Cheap) Nature and (capitalizing) Society. ${ }^{29}$ These are racializing assemblages ${ }^{30}$ they individuate humanity not only as separable from nature, but give a "hieroglyphics of the flesh," ${ }^{31}$ individuating White humanity in distinction to black and brown "exploitable nonhumans, literal legal no-bodies." ${ }^{32}$ In societies of control, the promise of equity becomes a dividuated diversity. If equity carries the promise of inclusion in acts and in spirit, or a determinate and indeterminate inclusion, dividuated diversity is its "skim milk" version. ${ }^{33}$ Diversity gives a determinate and exchangeable inclusion in place of full equity. Diversity, rather than producing multiplicities of connections and possibilities, becomes a nonperformative, ${ }^{34}$ an "appearance of valuing" 35 that allows racializing assemblages to continue producing its dualities unimpeded. The Capitalocene, control, and biopolitics, beyond being nonparticular to $\mathrm{AHE}$, elide sustained discussion of their colonizing and racializing productions. The particular formation of these relations and orientations of heterogeneous elements in this moment in AHE is what I term data-driven control.

\section{Disentangled relations, determined dividuals, data-driven control}

Data-driven control marks the organization of the heterogeneous elements of American higher education into data, dollars, Pell eligibility, term credits carried, and other discrete and measurable actants, or dividuals. ${ }^{36} \mathrm{AHE}$ provides stark examples of dividuation, as many administrators, faculty, and staff no longer primarily interact with students but on dividuals such as participation counts in high-impact practices, GPA, race, ethnicity, student identification numbers, predictive analytics, first-year credit accumulation, primary major, four-year graduation rates, and, and, and.... These dividual flows come into relation with their exchangeability through common units of value and are

28 Gerald Raunig, Dividuum: Machinic Capitalism and Molecular Revolution, Vol. I (South Pasadena, CA: Semiotext(e), 2016), 133.

29 Moore, Capitalism in the Web of Life.

30 Alexander G. Weheliye, Habeas Viscus: Racializing Assemblages, Biopolitics, and Black Feminist Theories of the Human (Durham, NC: Duke University Press, 2014).

31 Hortense Spillers, as cited in Ibid., 39.

32 Ibid., 135.

33 Transcript of Oral Argument at 71, United States v. Windsor, 133 S.Ct. 2675 (2013).

34 Sara Ahmed, On Being Included: Racism and Diversity in Institutional Life (Durham, NC: Duke University Press, 2012).

35 Ibid., 59.

36 Deleuze, "Postscript"; Raunig, Dividuum. 
placed in continuous variation in search of desired outcomes such as fouryear graduation. The university has transformed its space to make natural these orientations of flows ${ }^{37}$; in doing so, concepts involving indeterminacy such as liberal education ${ }^{38}$ and systemic racism are unintelligible, as they cannot be known through determinate, molar dividuum. AHE takes as its subject the in/dividual student: student-centered in spoken commitment and dividual-centered in practice.

Financially instrumentalist AHE is a creation of the agential cuts of datadriven control. Dividuals in AHE come in the above-listed forms, as well as in the form of grant money, assets (traditional forms of capital and as a synonym for students), debts, risk levels (financial aid and academic performance), and so on. Data-driven control is marked by deterritorialization and dividuation on a broad scale, and the relation and interchangeability of dividuum make possible huge flows of dividuals placed in variation. Outside of AHE, these flows have proven so massive as to produce the Capitalocene. Within AHE, we now have a conception of success that is calculable by the cost in lost wages and additional tuition of extra terms of schooling, or "extra" credits past the minimum to earn a degree, a placing-in-variation of terms, credits, wages, and tuition. Time, money, and success are disentangled through datadriven control, and that which resists dividuation (e.g., liberal education, systemic racism, and other webs of entangled relations) are rendered invisible to this agential system of determinate relations and flows.

Data-driven control also produces racist outcomes. The apparatus of data-driven control in undergraduate student success assigns as much matter as possible to content; it produces a science in which all representations of student visible to the institution are assigned to categories of success or failure. ${ }^{39}$ When institutions know students as dividuals, the push comes to target students deemed failing to attain checklists of dividuum determined to correspond with institutionally visible success. Approaches to undergraduate education that center the production of a dividual student success create the boundaries of failure and position those producing data-driven research as the link to solutions that never materialize. ${ }^{40}$ Data-driven control sets students up to fail, gives data-driven reformers a "problem" to fix, and gives

37 Slaughter and Rhoades, Academic Capitalism and the New Economy.

38 AAC\&U, "What Is 21 st Century Liberal Education."

39 See Gilles Deleuze and Felix Guattari, A Thousand Plateaus: Capitalism and Schizophrenia (Minneapolis: University of Minnesota Press, 1987), 369.

40 Patti Lather and Elizabeth St. Pierre, "Post-qualitative Research," International Journal of Qualitative Studies in Education 26, no. 6 (2013): 629-33. 
corporations a "solution" to sell. ${ }^{41}$ This structure produces structural failures of students of color alongside the success of White students; through datadriven dividuations, measurements of student success are racializing assemblages. ${ }^{42}$ Student success under data-driven control produces a "sovereign, hierarchical, and exclusionary subject," 43 that of the disproportionately White successful student.

In AHE, universities increasingly define student success as four-year graduation, name this on-time graduation, and undertake data-driven steps such as the promotion of 15 credits carried per term, clear degree plans and major benchmarks, and metamajors to "normalize" first-year exploration, among other innovations. ${ }^{44}$ And still, with each new data-driven practice, we have the same racialized pattern of data-determined success. Four-year graduation is in part justified as a valid way to measure success through capital: additional time in college past four years is time in which a student gives money to their institution rather than time they earn money from an employ$\mathrm{er}^{45}$ Even when considering only the subset of students deemed successful, when we send graduates to the workforce, White graduates are more likely to get a job and get better paying jobs than comparably qualified graduates of color, rendering the postcollege justification behind the category of success as racialized as determinations of success within the college years. ${ }^{46}$ There is a racial component to success as four-year graduation that is not only illegible within data-driven control, but also perpetuated through its naturalizing of the category of success alongside its conception of a measurable, discrete, Whitewashed student. The apparatus of data-driven control produces racist

41 EAB, Student Success Collaborative (Washington, DC: Educational Advisory Board, 2017). https://www.eab.com/technology/student-success-collaborative.

42 Weheliye, Habeas Viscus.

43 Rosi Braidotti, Nomadic Subjects: Embodiment and Sexual Difference in Contemporary Feminist Theory, 2nd ed (New York: Columbia University Press, 2011), 150.

44 Complete College America, Corequisite Remediation: Spanning the Completion Divide. Breakthrough Results Fulfilling the Promise of College Access for Underprepared Students. Executive Summary (Indianapolis, IN: Complete College America, 2016). http://completecollege.org/spanningthedivide/wp-content/uploads/2016/01/ CCA-SpanningTheDivide-ExecutiveSummary.pdf.

45 Complete College America, Four-year Myth: Make College More Affordable. Restore the Promise of Graduating on Time (Indianapolis, IN: Complete College America, 2014). http://completecollege.org/wp-content/uploads/2014/11/4-Year-Myth. pdf.

46 Ben Casselman, "Race Gap Narrows in College Enrollment, But Not in Graduation," FiveThirtyEight, accessed April 30, 2014. http://fivethirtyeight.com/features/racegap-narrows-in-college-enrollment-but-not-in-graduation/. 
success in a perverse way, as the disparate racial outcomes these success measurements generate serve as evidence that more data-driven studies, as well as data-driven, or evidence-based, practices, are needed to resolve these disparate racial outcomes. Systemic racism is produced and sustained through data-driven control.

Working the problem of undergraduate student success through datadriven control generates options for critique and change. The determinateindeterminate are one of several dualisms that describe the tension between student success practices that produce and sustain instrumentalized and racist success in the name of data science, and student success practices of radically open futures. AHE's commitments to socially just and student-centered practice through data machines the in/dividual student as AHE's subject, the instrumentalized, racialized student produced by institutions that pair nonperformative commitments to indeterminacy with performed commitments to dividuals.

\section{The Undergraduate Student Success Movement Comes to Great State University: The Particulars of This Epoch}

Below are three diffractions from the first year of Great State's student success initiative. Data sources are observation field notes and site documents from a year-long study of this student success initiative. In all, hundreds of hours of observations and informal interviews took place. Groups and persons involved include committees, councils, professional staff, students, faculty, and senior administrators. One is a narration of the flow of packets of student success within a local Great State University apparatus of data-driven control. This narration, in performing its movement, is structured as a fractured narrative of direct quotations (in italics) from field notes. One is focused on the role of capital in structuring this control context and the packets it places into variation. One foregrounds the role of race lurking in the background of the first two diffractions; or, one highlights the Whiteness starkly apparent in the first two diffractions. These are three of many possible diffractions that together map the particulars of data-driven control.

\section{Diffraction: Packets of student success-already, we'll all float on, okay}

Our new advising software is intended to use predictive analytics to facilitate more targeted advising. / So are you using data to determine...? So what's the...? / It's hard, because I see some students' registration and see that they're 
exploring, look undeclared - and I want to pass that student off...? / We could say students who enter as freshmen, leave transfers out - transfers don't matterwell it'sgood they graduate - but they don't count towards our graduation rate. I We need to bind the students together so they come together and leave together. I We need cohort branding. I It feels a little bit like cohort-building follows from infrastructure building. / Posters distributed by the institution: We want YOU... to graduate in four years with the school mascot in place of Uncle Sam. / Regarding the freshman class photo: It looks like Nazi propaganda.

We need an articulation of the moon shot that isn't just about a metric - this is the issue with many big campus talks/messages-need aspirational, mission/ vision content. / To the Faculty Senate: And this is again, part of a broader conversation about undergraduate educational experience. I've been working with [administrator] on our Student Success Initiative. That, in terms of graduation rates, is about raising our four-year graduation rates. But it's also about the undergraduate educational experience. How do we make sure that students not only get out in four years, but that they have a really rich experience while they're here? / Post-conference update: Everyone is saying the stuff we're saying - is everyone doing it? No. / What does it mean to say student success is a priority if we don't fund it?

We have a public mission as a public university. / We've got a system now that provides too much choice to students. / In my mind, as we're moving toward a bit more constrained curriculum, we'll be limiting exploration. / Our culture is to tell students to explore, but times have changed. / We have a student working on gathering four year plans from campus websites - [the] work there is in milestones - imagine the most common path... say to students this can be done in four years, [and] this is the most common way to do this. / We need to stop managing for the exceptions and manage for the majority.

\section{Diffraction: The Shape of the River, Brought to you by Capitalism ${ }^{\mathrm{TM}}$}

Tucked into this student success initiative is a little-spoken motivation: promoting four-year graduation is a way to blunt the per-student impact of rising tuition rates. At Great State University, this state-centered and institution-centered motivation was mentioned once in the major campus rollout address, but has since receded into the background. In its place, we have the rhetoric of a student-centered capitalistic valuing of purchasing a bachelor's degree in as little time as possible, with an overall credit accumulation as close to the minimum number of credits required to graduate as possible. In this student-centeredness lies a rhetoric of care, equity, and proper prioritization. However, the university no longer deals with students. The constituents of 
the university are dividuals. The university admits combinations of dividuals within admission applications. It grants financial aid to combinations of packets within the FAFSA. It grants degrees to combinations of dividuals within student information systems (SISs). In many large-enrollment classes, professors deliver an education to dividuals within learning management systems (LMSs). Advisors may see in/dividual students face to face, and when they do, it is increasingly likely that the students they see are the result of outreach campaigns that gather combinations of dividuals together from SISs and LMSs that are thought to determine in/dividual students who are at risk. When these dividuum become the interlocutor between the institution and its students, it becomes easier to see how time, money, and education have become fungible university outputs orientated by the Capitalocene, fashioned by data-driven control.

\section{Diffraction: Molar melanin}

Race is present at and around this site in myriad ways. Donald $\operatorname{Tr}^{*} \mathrm{mp}$ is in the process of winning the electoral college on the strength of White grievance politics. Black students on this campus presented a list of demands the year before, all coming due during this year, and upper-level administrators feel the pressure to do something. The lack of black and brown representation in the student body, faculty, and administration ranks is obvious enough to be a constant casual target of scorn among administrators and practitioners: "There are only two of us... one... two," followed by a painful laugh and a well-meaning resolve to do right by minoritized racial and ethnic groups. Data-driven control is a racializing assemblage, an arrangement of race that involves good feelings about non-White folks disproportionate to the amount of seats for non-White folks at the table.

The spoken commitment to racial equity and justice is pervasive. I do not doubt the sincerity of my participants' commitments. How can they produce racial justice? In the charge of a group devoted to writing a best-practicesfor-advising report for campus:

Research targeted initiatives for specific populations (underrepresented students by race, gender, transfer, international, first-gen, lower income, abilities...)... Form recommendations for student centered service, practices, and expectations that support student retention while being in [sic] degree completion... These strategies should include specific elements for serving targeted populations.

A sincere commitment to racial justice from the administrator developing these charges to the advisors who gave of their time to participate. By what criteria would targeted initiatives make the list of recommendations? 
1. Existing research in the field (NACADA)

2. Internal audit (retention rates/satisfaction), compare with advising models across units, factor in unique considerations of each unit

3. Review comparable institution data (student pop, majors, advising models, retention)

4. What resources are needed to facilitate successful advising (space, training, professional development), including adhering to FERPA requirements.

Racially just action can be known through a heterogeneous arrangement of dividuals placed in variation, the same procedure for knowing best practices writ large: "Retention rates-satisfaction-advising models-unique considerations-comparable institutions/student population-comparable institutions/majors-comparable institutions/advising models-comparable institutions/retention-advising space-advisor training-advisor PD." Find the right notes, the right lengths, the right layerings and chord progressions, and place in variation. Yet this refrain lacks the indeterminacies found in performance. ${ }^{47}$ This is a continuous algorithmic variation, a flow of determinacy. GSU harbors and produces a racializing assemblage, an arrangement of race that involves race as molar melanin, "statistical and gregarious." 48 Racism is a problem that far exceeds the capacity of collections of dividuals to solve, no matter how gregarious, no matter in what combination or variation. And yet, this excess gives reason for its molarized study.

Race here is dividual; race is a multiplicity found as a field in the institutional SIS, or as a field in a survey like the NSSE administered by the institution, and through its inclusion becomes a method of disaggregation of a gregarious arrangement of dividuals. Diversity is a metric, is a dividual within institutional plans for student success, is a dividual within institutional budget metrics to incentivize the three named institutional priorities, including student success (We're number 2! We're number 2!).

Administrator 1 [Al]: "TAdministrator 3, A3] has completely changed his third goal to diversity... I told you [A3] did it with the accreditors, now [A3] just did it with the Senate."

$<$ Room explodes in amazement.>

Administrator 2: "What was the third one?"

$\mathrm{Al}$ : "Experience, student experience-now it's diversity."

47 Deleuze and Guattari, A Thousand Plateaus.

48 Ibid., 283. 
Welcome to the top three, diversity. The institution plans to pursue their top priorities through the then-currently-being-drafted new campus budget metrics. One late draft includes a set of diversity metrics, all determined categories placed in variation, including

- Breakdown in asterisked performance categories by demographics: residency status; race/ethnicity; gender; first-gen; Pell eligibility - Faculty participating in inclusive teaching initiatives - \# Gorst want to incentivize more courses]- learning objectives at the department level that tend toward diversity, equity and inclusion - \% of courses that align to those objectives... [National survey] climate data-

Race is a deeply held commitment; race is dividual. GSU is student-centered and evidence-based.

\section{Indeterminacy and Open Futures}

Indetermination eschews discrete and measurable dividuals produced by the apparatus of data-driven control in favor of the incorporeal, virtual relations as experienced within Events. Orientating racism not as a property of an individual, but as "the inseparability of a finite number of heterogeneous components traversed by a point of absolute survey at infinite speed" 49 allows for the inclusion of actants both determinate and indeterminate. The indeterminate character of systemic racism-racism that is real and escapes determination within data-driven control-is not opposed to currently legible overt individual racism. To take seriously the claim that indeterminacy is every bit as real as the determinate is simply to acknowledge that "experience is made up of more than what actually takes form." ${ }^{50}$ To claim that systemic racism is every bit as real as individualized racism is to acknowledge that the experience of racism "is made up of more than what actually takes form"; to claim that education irreducible to measurable outcomes is every bit as real as education made legible through measurable outcomes is to acknowledge that education "is made up of more than what actually takes form." ${ }^{51}$ Thus, an embrace of indeterminacy gives us insight into pre-in/dividual, pre-in/dividuated racism as well as a pre-in/dividual, pre-in/dividuated student success.

To be clear, an embrace of indeterminacy - a queer dis/orientation to the interstices of data-driven control-is not the answer to data-driven control

49 Gilles Deleuze and Felix Guattari, What Is Philosophy? (New York: Columbia University Press, 1994), 21.

50 Ibid., 30.

51 Ibid. 
nor the Capitalocene. ${ }^{52}$ Indeterminacy does not produce a state of liberation from data-driven control. A disorientation from the Capitalocene will bring some bodies into crisis more than others. ${ }^{53}$ Even still, we owe each other these leaps of faith in order "to give the lie to our own determination. We owe each other the indeterminate. We owe each other everything." ${ }^{54}$ Our current student success apparatus has two faces, one of which gives us the racialized and instrumentalized categories of successful and unsuccessful. The first step to any practice which seeks to address systemic racism and the instrumentalization of undergraduate education is to turn our attention to the other face of the assemblage to break those categories apart. Instead of reforming flows of dividuals to produce a racially just student success, ${ }^{55}$ student success as liberal education, ${ }^{56}$ a solution to the Anthropocene through Green Arithmetic, or otherwise confining our actions to data-driven deformings and reformings of flows, practice that tips toward indeterminacy asks us to turn our attention to the other face, to dis/orientate ourselves, and in doing so hold these dividuations and flows radically open and subject to immanent formation and reformation. Through resisting cycles of deforming and reforming dividuals, this disorientation leaves maximum space for encounters with the indeterminate, the real but not-yet-determined.

\section{The Queer Possibilities of Liberal Education}

An embrace of indeterminacy is a disorientation from our current production of in/dividualized persons and an orientation toward the production of "open-ended, interconnected entit[ies]." ${ }^{57}$ Liberal education queers the surface connecting determinacy and indeterminacy, and its potential to tip the apparatus of data-driven control from determinacy toward the face of indeterminacy foregrounds practices in an acknowledgment that experience "is alive with the more-than, the more-than as real as anything else directly experienced." 58 Data-driven control denies the more-than by assigning all contents to categories, here assigning all in/dividuated students to racialized categories of successful or unsuccessful. Indeterminacy as practiced through

52 Deleuze and Guattari, A Thousand Plateaus.

53 Ahmed, Queer Phenomenology.

54 Stefano Harney and Fred Moten, The Undercommons: Fugitive Planning and Black Study (Brooklyn, NY: Minor Compositions, 2013), 20.

55 Complete College America, Four-year Myth.

56 Kuh and Schneider, High-Impact Practices.

57 Braidotti, Nomadic Subjects, 150.

58 Erin Manning, The Minor Gesture (Durham, NC: Duke University Press, 2016), 30. 
liberal education affirms the more-than by individuating through "by following the border, by skirting the surface [to pass] from bodies to the incorporeal." 59 Liberal education, as a practice that queers the surface of determinacy and indeterminacy, is a dividual-buster. Instead of an orientation toward the ordering of words and things through dividuals, liberal education is orientated toward practices that create new and shifting understandings of words and things. In doing so, liberal education can individuate and address instrumentalization and systemic racism that, as the more-than of a traditionally in/dividuated data-driven research, remains naturalized, Whitewashed, and denied.

The work of anti-instrumentalist and antiracist student success research and practice in the Capitalocene is not to reimagine student success only under conditions of indeterminacy, but to map student success under both determinate and indeterminate conditions. In doing so, we tip the assemblage toward an entangled science of student success, giving researchers and practitioners a language to discuss real social events that are not instantiated in in/dividuated human actors - it gives the field the language of the indeterminate. Liberal education is this mechanism, it is the surface, it is the little machine that is ready when needed for researchers looking to tip the research assemblage away from data-driven student success measurements that render systemic racism and other indeterminacies as an invisible excess, and toward practices that acknowledge the more-than of liberal education and systemic racism as real.

Promiscuous proliferations of concepts and practices placed in relation queerly re/orientates American higher education toward liberal education in the Capitalocene. We need a proliferation of student success practices that perform commitments to a trans-corporeal liberal education and other expansive notions of success. ${ }^{60} \mathrm{We}$ need a politics of the dividual that produces a proliferation of student success practices with performed commitments to diversity, social justice, and antiracism that lead to racially just education-a justice that is and is not capturable within measurement. ${ }^{61}$ We need a molecular revolution, a proliferation of pedagogies and relations that removes undergraduate education from calculations of time and money and produces outcome that is and is not capturable in such systems. ${ }^{62}$ A proliferation of practices queering

59 Gilles Deleuze, The Logic of Sense (New York: Columbia University Press, 1990), 10.

60 Stacy Alaimo, Bodily Natures: Science, Environment, and the Material Self(Bloomington, IN: Indiana University Press, 2010).

61 Brian Massumi, The Power at the End of the Economy (Durham, NC: Duke University Press, 2015).

62 Raunig, Dividuum. 
the surface disorientates the Capitalocene. We are in the middle of the orientation of the Capitalocene and data-driven control; our task is to tip its orientation through a queer commitment ${ }^{63}$ to liberal education.

\section{References}

AAC\&U. What is a 21st Century Liberal Education? Washington, DC: American Association of Colleges \& Universities, 2017. https://aacu.org/leap/what-is-a-liberaleducation.

Ahmed, Sara. Queer Phenomenology: Objects, Orientations, Others. Durham, NC: Duke University Press, 2006.

- On Being Included: Racism and Diversity in Institutional Life. Durham, NC: Duke University Press, 2012.

Alaimo, Stacy. Bodily Natures: Science, Environment, and the Material Self. Bloomington, IN: Indiana University Press, 2010.

- Exposed: Environmental Politics and Pleasures in Posthuman Times. Minneapolis, NC: University of Minnesota Press, 2016.

Astin, Alexander W. Four Critical Years: Effects of College on Beliefs, Attitudes, and Knowledge. San Francisco, CA: Jossey-Bass, 1977.

Atkinson, Becky. "Was Jane Addams a Promiscuous Pragmatist?" International Journal of Qualitative Studies in Education 26, no. 5 (2013): 610-24.

Barad, Karen. Meeting the Universe Halfway: Quantum Physics and the Entanglement of Matter and Meaning. Durham, NC: Duke University Press, 2007.

Beyoncé. Formation. Columbia, 2016, digital.

Braidotti, Rosi. Nomadic Subjects: Embodiment and Sexual Difference in Contemporary Feminist Theory. 2nd ed. New York: Columbia University Press, 2011.

Burke, Michelle, Amelia Parnell, Alexis Wesaw, and Kevin Kruger. Predictive Analysis of Student Data. Washington, DC: NASPA: Student Affairs Administrators in Higher Education, 2017. https://www.naspa.org/images/uploads/main/PREDICTIVE_ FULL_4-7-17_DOWNLOAD.pdf.

Casselman, Ben. "Race Gap Narrows in College Enrollment, But Not in Graduation." FiveThirtyEight. Accessed April 30, 2014. http://fivethirtveight.com/features/racegap-narrows-in-college-enrollment-but-not-in-graduation/.

Colebrook, Claire. "We Have Always Been Post-Anthropocene: The Anthropocene Counterfactual." In Anthropocene Feminism, edited by Richard Grusin, 1-20. Minneapolis, MN: University of Minnesota Press, 2017.

Complete College America. Four-year Myth: Make College More Affordable. Restore the Promise of Graduating on Time. Indianapolis, IN: Complete College America, 2014. http://completecollege.org/wp-content/uploads/2014/11/4-Year-Myth.pdf.

63 Ahmed, Queer Phenomenology. 
Corequisite Remediation: Spanning the Completion Divide. Breakthrough Results Fulfilling the Promise of College Access for Underprepared Students. Executive Summary. Indianapolis, IN: Complete College America, 2016. http://completecollege. org/spanningthedivide/wp-content/uploads/2016/01/CCA-SpanningTheDi vide-ExecutiveSummary.pdf.

Coole, Diana, and Samantha Frost. "Introducing the New Materialisms." In New Materialisms: Ontology, Agency, and Politics, edited by Diana Coole and Samantha Frost, 1-43. Durham, NC: Duke University Press, 2010.

Crist, Eileen. "On the Poverty of our Nomenclature." In Anthropocene or Capitalocene? Nature, History, and the Crisis of Capitalism, edited by Jason W. Moore, 14-33. Oakland, CA: PM Press, 2016.

Deleuze, Gilles. The Logic of Sense. New York: Columbia University Press, 1990. . "Postscript on the Societies of Control." October 59 (1992): 3-7.

Deleuze, Gilles, and Felix Guattari. A Thousand Plateaus: Capitalism and Schizophrenia. Minneapolis: University of Minnesota Press, 1987.

- What is Philosophy? New York: Columbia University Press, 1994.

- Anti-Oedipus: Capitalism and Schizophrenia. New York: Penguin Books, 2009.

EAB. Student Success Collaborative. Washington, DC: Educational Advisory Board, 2017. https://www.eab.com/technology/student-success-collaborative.

Feldman, Kenneth A., and Theodore M. Newcomb. The Impact of College on Students, Volume 1: An Analysis of Four Decades of Research. San Francisco, CA: Jossey-Bass Inc., Publishers, 1969.

Foucault, Michel. The History of Sexuality, Volume 1: The Will to Know. New York: Vintage Books, 1990.

—. The Birth of Biopolitics: Lectures at the Collège de France 1978-1979. New York: Palgrave Macmillan, 2008.

Haraway, Donna. “Anthropocene, Capitalocene, Plantationocene, Chthulucene: Making Kin.” Environmental Humanities 6 (2015): 159-65.

Harney, Stefano, and Fred Moten. The Undercommons: Fugitive Planning and Black Study. Brooklyn, NY: Minor Compositions, 2013.

Hubbard, Saul. “Out-of-State 'O'ffensive: UO Widening Net to Recruit Nonresidents to Reverse Enrollment Dip.” Eugene Register-Guard. Accessed October 8, 2017. http://registerguard.com/rg/news/local/36001005-75/out-of-stateoffensive. html.csp.

Jackson, Alecia Y., and Lisa A. Mazzei. Thinking with Theory in Qualitative Research: Viewing Data Across Multiple Perspectives. New York: Routledge, 2012.

Kuh, George D., and Carol Geary Schneider. High-Impact Practices: What They Are, Who Has Access to Them, and Why They Matter. Washington, DC: American Association of Colleges and Universities, 2008.

Lather, Patti, and Elizabeth St. Pierre. "Post-qualitative Research." International Journal of Qualitative Studies in Education 26, no. 6 (2013): 629-33.

Manning, Erin. The Minor Gesture. Durham, NC: Duke University Press, 2016. 
Massumi, Brian. Parables for the Virtual: Movement, Affect, Sensation. Durham, NC: Duke University Press, 2002.

- The Power at the End of the Economy. Durham, NC: Duke University Press, 2015.

Moore, Jason W. Capitalism in the Web of Life: Ecology and the Accumulation of Capital. London: Verso, 2015.

Nail, Thomas. "Biopower and Control." In Between Deleuze and Foucault, edited by Nicolae Morar, Thomas Nail, and Daniel W. Smith, 247-63. Chicago: University of Chicago Press, 2016.

Raunig, Gerald. Dividuum: Machinic Capitalism and Molecular Revolution, Vol. 1. South Pasadena, CA: Semiotext(e), 2016.

Schneiderman, Jill S. "The Anthropocene Controversy." In Anthropocene Feminism, edited by Richard Grusin, 169-95. Minneapolis: University of Minnesota Press, 2017.

Slaughter, Sheila, and Gary Rhoades. Academic Capitalism and the New Economy: Markets, State, and Higher Education. Baltimore, MD: The Johns Hopkins University Press, 2004.

Smithers, Laura E. "A History of the Present of Student Success in Undergraduate Education." Unpublished manuscript. Last modified March 1, 2018. Microsoft Word file.

Ulmer, Jasmine B. "Posthumanism as Research Methodology in the Anthropocene." International Journal of Qualitative Studies in Education 30, no. 9 (2017): 832-48.

Weheliye, Alexander G. Habeas Viscus: Racializing Assemblages, Biopolitics, and Black Feminist Theories of the Human. Durham, NC: Duke University Press, 2014. 